\title{
Developing an optimal pattern for state intervention in urban land management: case of Iran, Tehran city
}

\author{
Abolfazl Meshkini ${ }^{1} \cdot$ Mehdi Normohamadi $^{1} \cdot{\text { Moslem } \text { Zarghamfard }^{1}}^{1}$
}

Received: 24 December 2018/Revised: 7 May 2019/Accepted: 11 May 2019/Published online: 16 May 2019

(C) The Author(s) 2019

\begin{abstract}
Land management is a key requirement for sustainable development. This research aimed to explore the challenges of state intervention in the land management system in Iran. In particular urban land is one of the most important issues in managing the city of Tehran, which has caused many challenges. The research seeks to investigate the inefficiencies of state intervention in urban land management. Also it seeks to formulate and develop a pattern for state intervention through a mixed research. In this research, data were collected through questionnaires, interviews and etc. Also sample size was 350 . The results show that optimal urban land management requires an integrated land management approach consisting of a transparent vision and interactive approach among urban landlords. In addition the state intervention in the four areas of land management (ownership, use, taxation, and development) should be consistent across the land.
\end{abstract}

Keywords Policy making · State intervention · Urban land management $\cdot$ Land policy $\cdot$ Tehran $\cdot$ Iran

\section{Introduction}

Along with water, oxygen, carbon dioxide, nitrogen, sunlight, and other necessities, land is one of the main constituents of life on Planet Earth [1]. In classical political economy (the predecessor to modern economics), land,

Abolfazl Meshkini

meshkini@modares.ac.ir

1 Department of Geography and Urban Planning, Faculty of Humanities, University of Tarbiat Modares, Jalal Street, Tehran, Iran capital, and labor constitute the three factors of production [2]. Kivell [3] believes that land has two major roles in urban development. According to Kivell, land reflects the urban morphology and power, which together form the basis of urban development [3]. Ryan-Collins et al. [2] argue that land values in a place reflect the level of wider economic activity in that place. In general, availability of land and infrastructure is a prerequisite for economic growth at any level $[4,5]$. In developing countries, globalization and rapid urban development have generated dynamic changes in large cities, which have led to extensive land use changes. In these countries, fast population growth has also created a wide range of urban problems [6-10], as the consequent expansion of industry and transport systems has ushered in an unprecedented level of urbanization [11]. Land preparation is one of such problems. In the urbanization process, land is one of the most important pillars [11-13]. According to Kelly [14], the transformation of rural lands to urban landscapes in the course of urbanization is an adverse phenomenon. He believes that seizing rural lands and using them for urban purposes leads to land instability, as it impairs integrated land management [14]. With the transition of land from rural to urban, different land tenure and administration systems may come into conflict with one another [15]. As Shan et al. [16] have argued, land acquisition by the government might also lead to social conflicts. Hence, land accessibility, land tenure, and land use should be well considered while planning urban development [17].

Interventions in the urban land development process could be seen as a duty or function of the government. According to Rakodi [18], land policies and practices are typically adopted periodically, but from time to time specific policies might be required to address specific challenges. Hence, land management can be affected by 
societal drivers such as poverty eradication, gender equality, recognition of indigenous rights, adequate housing, sustainable agriculture, food security, climate change response, and good governance initiatives [19]. The everrising need for land management and infrastructure development because of rapid urban growth is among the major challenges that many developing countries face in their struggle against urban governance problems. Iran has also undergone rapid urbanization in the past decades.

According to Molaeiqelichi et al. [20], over the past four decades, Iran has experienced two major socio-demographic phenomena: population growth and urbanization. Population growth result in a growing demand for housing, which forces the governments to acquire lands and designate them as residential zones [21]. In Iran, as well as many other counties, rapid urbanization has been accelerated by the effects of modernization and globalization. As a result, the population of many Iranian cities has significantly increased in recent times. Tehran, the capital of Iran, has seen the largest population growth, which can be attributed to steady migration from other cities as well as rural areas. This population growth has created a lot of problems for the management of Tehran, especially in regard to housing. Naturally, governments need land to provide housing and a major portion of urban lands has to be used for housing purposes. What ails the management of Tehran is the lack of integrated land management and the absence of a proper land allocation system. It can be said that urban land management in Tehran is not consistent with the goals of sustainable development. Given the critical importance of land management for Tehran and the lack of an effective system for this purpose, this paper proposes a land management model for this city. This model aims to help the government implement effective interventions in the management of urban lands and thus address the dire need for such land management system in the city of Tehran. In this way, we seek to answer the following question.

What is the optimal pattern for state intervention in urban land management in Tehran?

\section{Literature review}

Land plays a key role in our life and the provision of essential goods and services [22]. With the rapid urbanization of the past decades, many urban areas are now facing severe land shortage problems [23]. This issue can be discussed in the framework known as sustainable land management. Sustainable land management means planning and policy making according to future economic, social, urban and ecological needs of the area and its population. The importance of this approach to planning and policy making stems from the significant role of land in human well-being. Integrated and purposeful land planning leads to rational and optimal use of land as a limited resource and its preservation for future generations. According to Nubi and Ajoku [24], land, with its associated buildings and developments, is one of the most important assets of any country and affects almost every other investment. In this paper, the focus is on urban lands.

Urban land refers to a land that is used for constructions purposes [25] and has special features that cannot be bought and sold like other commodities in the capital market [26]. It also refers to a land that is located within the city boundaries and cannot be built upon without a permit from a municipality. Rithmire [27] believes that urban land can be viewed simply as a commodity, but territorial politics emerge when different factions compete to dominate it. According to Lefebvre [28], since each city has been created by "all" people of its community, it can be argued that urban land belongs to all members of the community $[28,29]$. George [30] believes that the lands of a city are not owned by a person or company, but belongs to everyone living in that city. One of the major duties of urban governments is to plan and implement the policies needed to ensure the optimal use of urban lands. The laws, methods, and tools that governments use, directly or indirectly, to achieve this goal are called "urban land policy". Urban land policy can be viewed as one of the branches of public policy. It involves governments adopting a specific policy according to the objectives of their system and political, socio-economic and geographical conditions of their area of responsibility.

Progress in human knowledge about the complexities of modern urban environments has led to the emergence of multiple management approaches for urban areas [31]. There are two major approaches to land administration: public governance and private governance (also called 'active' and 'passive' approaches). The suitable approach to each issue depends on institutional, financial and environmental factors and may change with time [32]. Governments can play both a passive regulatory role through public planning (being the 'referee') and an active role through public land ownership (being a 'player') [33]. The quality of our environment is also directly associated with land management [34]. Hence, land management is another issue that needs attention in the discussion of urban land issues. Land management can be divided into three subsystems: land development, land ownership, and land activity [35]. From the institutional point of view, land management involves land policy information, legal framework, resource management, land management arrangements, and land data management. The primary purpose of urban land management is to guarantee social stability by macroeconomic regulation of 
the land market and reasonable allocation of land's fiscal revenues [9]. Urban land management is a system consisting of actors and related activities aimed at improving the allocation and utilization of urban space, especially land. In other words, the general purpose of urban land management is to guide and control the regular growth of cities so as to enhance their performance [11]. Optimal use of land can be achieved with the help of instruments such as land readjustment $[34,35]$, urban land consolidation [36] and land reform [37]. Land readjustment prevents the misuse of land. Land reform serves as a tool for stimulating progress in the development process. Land reform makes the economy more dynamic, which results in reduced poverty, and also stimulates land markets [37-40]. Eidelman believes that urban politics and governance in the land management process are dominated not by land developers but by the central government. Of course, land ownership by the government draws criticisms from various aspects.

There are four types of land in Iran: 1-forest lands, 2pastures and grazing lands, 3-agricultural lands or farmlands, and 4-lands under human settlement. Urban lands classify under "Lands under human settlement".

Since the research concerns state intervention in urban land management, the theories in this field should be reviewed. There are three theories about state intervention in urban land management: (1) Market-based system theory (neoliberal), (2) Intermediate theory, and (3) state intervention theory. Advocates of the market system support the policy of the government's non-interference in urban land management and believe that the allocation of land should be decided by market mechanisms (supply and demand). Advocates of the state intervention approach believe that land allocation should be fully dominated by the state so as to allow for rational use and respect for citizenship rights. If these two theories are two ends of a spectrum, the middle of this spectrum is occupied by a mostly Keynesian approach called "institutionalism", which advocates the government's involvement in the economy (Table 1).

State intervention in land management is generally classified in four areas of land registration, planning instruments, land development, and financial and legal instruments. From another perspective, state intervention can be classified into two types, direct and indirect. Direct intervention refers to land expropriation by the public sector (compulsory seizure of land, governance and land readjustment, land assembly and land subdivision; infrastructure provision and land development services/land preparation). Indirect control refers to the use of legal instruments (land use control, land ownership pattern determination, land ownership rights) and financial instruments (windfall profits tax, betterment tax, tax on vacant land, frequent transfer tax) (Fig. 1).

The most important goals of urban land policies include: preserving the natural environment, preparing infrastructure investment, developing, maintaining and enhancing property values, providing access to land for the poor and controlling land hoarding. In this study, we reviewed the literature in search of material regarding the goals of urban land policy. According to the results of this review, to achieve the above objectives, developing countries have to get ready to face the following challenges.

The problems listed in Table 2 are also present in Iran, but with a few differences. Given that land is mainly a public commodity, sustainable land management requires timely state interventions to align public and private interests, address market failures, and empower the market when necessary. Hence, the main focus of this study is the challenges and necessities of state intervention (Table 3).

\section{Methodology}

The quantitative-qualitative approach was used in this research. In order to collecting information, the authors used combination of official records, questionnaires, and in some cases, interviews with experts. Furthermore to analyze the data, we used the Atlas ti 6 and SPSS V21.0 software. Considering the theoretical works, previous studies, and past experiences of countries in the field of land management (based on Atlas 6), items of Table 4 were identified as the main factors of the ineffectiveness of state intervention in urban land management. First, indicators were extracted from the literature and a list of frequently emphasized items was created. Then, to localize the identified items for Iran, they were shared with a group of experts for evaluation. The items that did not conform to Iran's conditions were eliminated and the remaining items were used as final indicators. Statistical population of research include in two group: (1) all institutions responsible for urban land management in Tehran city and (2) clients of these institutions.

After defining the operational concepts, each concept was converted into measurable indices and indicators. To localize the indicators, the items were reviewed by the experts of land management (consisting of veteran managers and experts with more than 20 years of experience and researchers with academic record in the field of land management). Confirmed cases were converted into 
Table 1 Views related to state intervention in land management

\begin{tabular}{|c|c|c|c|}
\hline Theory & Intervention level & Schools of thought & Approach \\
\hline \multirow[t]{5}{*}{$\begin{array}{l}\text { Market-based system theory } \\
\text { (Neoliberal) }\end{array}$} & No intervention & $\begin{array}{l}\text { Classic political economy. } \\
\text { Neoclassic }\end{array}$ & Release of the land market \\
\hline & No intervention & Austrian School & \\
\hline & No intervention & Chicago School & \\
\hline & No intervention & Virginia School (Public Choice) & \\
\hline & No intervention & Anarcho-Capitalism School & \\
\hline Intermediate theory and & Proper intervention & Institutionalists & $\begin{array}{l}\text { Empowerment of nongovernmental and private } \\
\text { sectors }\end{array}$ \\
\hline \multirow[t]{3}{*}{ State intervention theory } & High intervention & Market based socialism & State intervention \\
\hline & $\begin{array}{l}\text { Too much } \\
\text { intervention }\end{array}$ & Radical & \\
\hline & High intervention & Islamic & \\
\hline
\end{tabular}

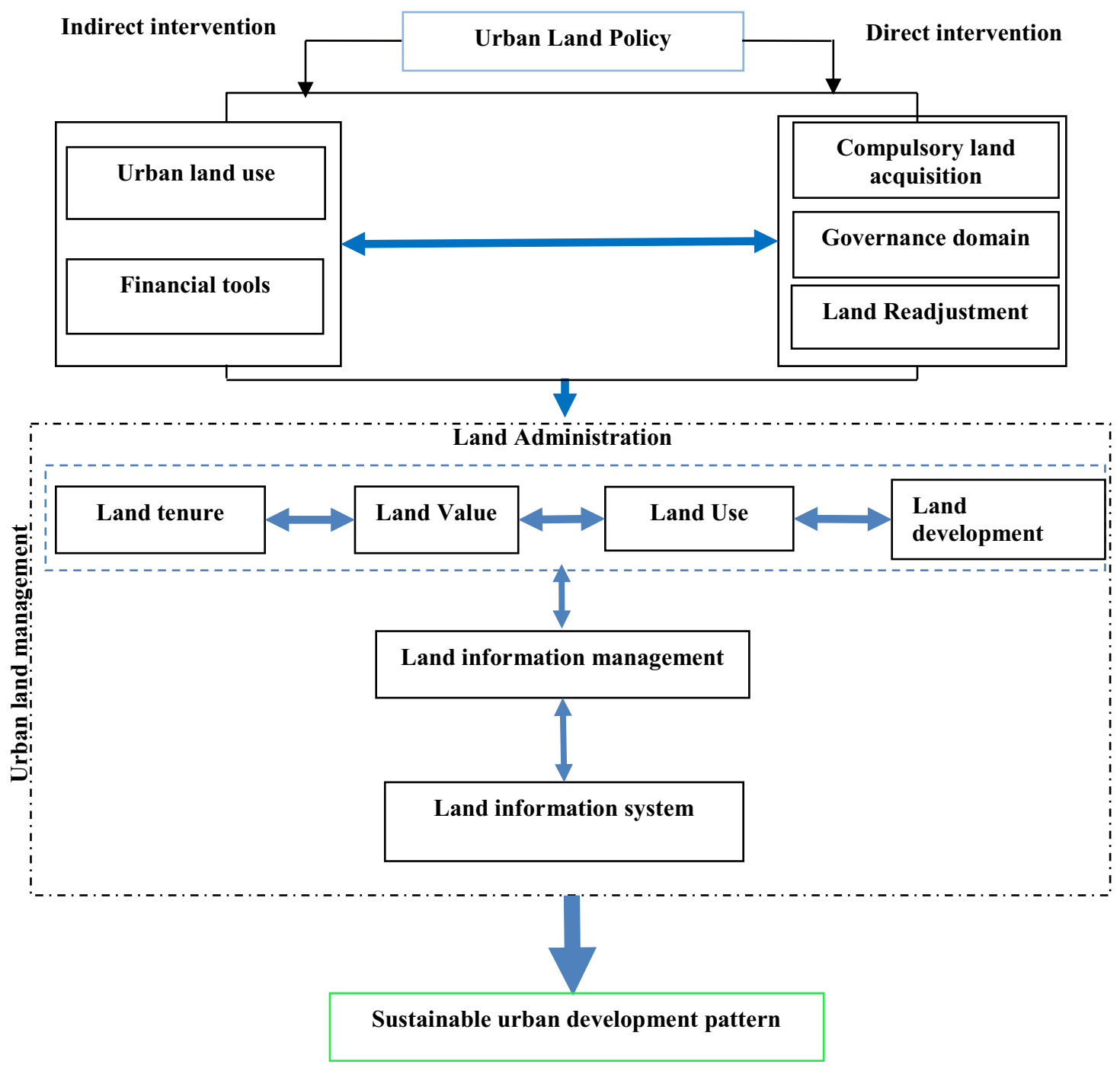

Fig. 1 Forms of state intervention in land management 
Table 2 Urban land policy issues in developing countries. Source: Authors

Intensive decision-making that results in the use of comprehensive (non-cooperative) approaches in urban planning based on costly and strong legal frameworks

Inefficient and old mechanisms for providing adequate land for urban growth

Lack of sustained infrastructure and services for housing demand in cities with rapid population growth due to the lack of financial resources and, more importantly, the weakness of management and the inconsistency of the bureaucratic institutions

Centralized policies and controls, and consequently an irregularity in the behavior of land market, and the inadequate performance of land and housing markets. unpredictable distribution of land resources

A faster rise in land prices, along with a low income level, limits the access of low-income groups to land

The lack of intelligent control of added value of land in urban development process

The contradiction of the infinite private ownership of land and, consequently, the destruction of the environment

Inefficient state-owned urban land development program (low level planning techniques for future urban growth). As a result, there is no suitable land and no suitable price

Weak coordination within the state sub-sectors; between the state and the private sector (the resistance of the private sector against the state's land regulations)

Centralized information systems and lack of efficient cadaster

Inefficient use of urban space and uneven urban development

State inefficiency in land supply

Lack of infrastructure services, adjacent urban undesirable elements, Lack of information, unlicensed public land, non-economic investment, lack of formal documentation, land sharing, administrative weaknesses causes the inefficient use of land

State intervention in the urban land market has been inefficient and has caused the disparate and disproportionate urban development

Lack of coordination between land ownership and its management with urban development plans is one of the main reasons for not realizing the plans

Lack of a program for regular land supply despite public land ownership; Undefined intervention; Very weak capacity of land management institutions

measurable items. Then, questionnaires were developed and distributed among target groups. Ultimately, the collected information was used to analyze the current state of intervention policy. Using Cochran method (see below formula), the sample size was calculated. Ultimately, a total of 350 questionnaires were distributed. ${ }^{1}$ The data were collected from Tehran municipalities and people visiting these institutions. For statistical analyses, the results were entered into SPSS V21. The Cochran formula is:

$n=\frac{\frac{Z^{2} p q}{d^{2}}}{1+\frac{1}{N}\left(\frac{Z^{2} p q}{d^{2}}-1\right)}$

where $\mathrm{N}=$ Population size, $\mathrm{n}=$ Adjusted sample size, $\mathrm{p}=$ Estimated proportion of the population which has the desired attribute, $q=(1-p)=$ Ratio of the absence of the desired attribute, $\mathrm{d}=$ Allowable error, $\mathrm{Z}=$ Value of the normal variable with the confidence level of $\alpha-1$ (Tables 5, 6).

\footnotetext{
1 The questionnaires were completed on the site and all the questionnaires were returned to the authors, because the authors themselves were communicating directly with people.
}

\section{Results and discussion}

In this section, we are looking for answers to the research question and we will have some analyzes in this direction. In this way, we must once again express the research question. Hence. Therefore, the research question is:

What is the optimal pattern for state intervention in urban land management in Tehran?

\subsection{Condition and ranking of components and dimensions}

As shown in Table 7, because of the absence of a clear vision, policies have been developed without inter-institutional coordination and are incoherent. The decision-making process in the field of land management is centralized and non-participatory and this impairs policy coherence at development, adoption, and implementation levels. Since policies are uncoordinated, the institutions responsible for implementing them come into conflict with one another during the implementation phase. In general, it is difficult to conceive a coherent policy without inter-institutional coherence and vice versa, because policies and institutions have bilateral and interrelated effects. In other words, on the one hand, a policy can be successful only if there is an 
Table 3 Main factors of the ineffectiveness of state intervention in urban land management. Source: Authors

\begin{tabular}{|c|c|}
\hline Factor & Operational definition \\
\hline Distinct/special vision $^{\mathrm{a}}$ & $\begin{array}{l}\text { The state intervenes in land management is clear. The responsibilities of land management in various dimensions } \\
\text { (land rights, land use, land market and land value and land tax) are the responsibility of numerous institutions } \\
\text { within the system. Therefore, a supra- institutional perspective with the participation of all shareholders has been } \\
\text { developed and desired conditions of state intervention in urban land management for future mapped out. Each } \\
\text { institution (with the formulation of introspective missions and adopting policies and strategies) will place itself in } \\
\text { the desired position. In this way, the performance of institutions will be mutually reinforcing and the efficiency of } \\
\text { land management will increase }\end{array}$ \\
\hline $\begin{array}{l}\text { Decision making and its } \\
\text { type }\end{array}$ & $\begin{array}{l}\text { The spatial decision-making powers are at the closest level to the local level and decisions are made by the local } \\
\text { level with the participation of all actors (shareholders) in a bottom-up manner }\end{array}$ \\
\hline Integration of policies & $\begin{array}{l}\text { Different policies (within the institutions or different sectors) are all in line with a specific perspective (at the level } \\
\text { of the system/enabling environment) and the policies adopted in land management are vertically (between the } \\
\text { central state and the local institutions and vice versa) and horizontally (with the policies of the different sectors) } \\
\text { are consonant }\end{array}$ \\
\hline Integration of institutions & $\begin{array}{l}\text { Each of the urban land management bodies has specific activities and transparent spatial coverage that prevent } \\
\text { parallel work and re-work. These institutions are horizontally (due to trust among them) by negotiating and } \\
\text { agreeing, contributing to decisions and activities, providing opportunities for the development of each other } \\
\text { views and ideas, and also vertically by constructive interaction with higher levels (National Institutions) work } \\
\text { together to achieve their vision goals }\end{array}$ \\
\hline Institutional capacity & $\begin{array}{l}\text { Institutional capacity is the power of an entity to perform its tasks, actions and pursue its goals. The set of external } \\
\text { and internal influential factors constitute institutional capacity. External factors includes: existence of a clear } \\
\text { vision, integrated policy, integrated institutions, type and level of decision making and internal factors includes: } \\
\text { human resources, resources, incentives and punishments, knowledge and learning, and inter-institutional } \\
\text { relationships network }\end{array}$ \\
\hline $\begin{array}{l}\text { Effectiveness of state } \\
\text { intervention }\end{array}$ & $\begin{array}{l}\text { The amount of achievement of the goals defined in the policies and regulations of the governing system and the } \\
\text { policy maker through the implementation of these policies by the responsible institutions, state of the land } \\
\text { market; land use and trend of rising land prices indicate the effectiveness of state intervention in land } \\
\text { management }\end{array}$ \\
\hline
\end{tabular}

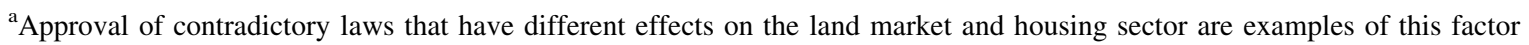

Table 4 Research components and dimensions. Source: Authors

\begin{tabular}{ll}
\hline Concept & Component \\
\hline Distinct vision & Supra-institutional vision \\
& Purposefulness \\
Integration of polices & Coordination of urban land policy with policies of other sectors (horizontally) \\
& Coordinating with higher level policies and documents (vertically) \\
Integration of institutions & Relationships inside institutions (vertical) \\
& Coordinated behavior of institutions \\
& Necessary institutional arrangements \\
& Inter-institutional social capital \\
Institutional capacity & Appropriate legal arrangements for coordination \\
Effectiveness of state intervention & The ability of institutions \\
& Education and learning \\
& Direct intervention \\
& Indirect intervention \\
\hline
\end{tabular}

institutional capacity for it, and, on the other hand, the performance of institutions depends on the existence of correct policies. If the policy is poor, the institutions, however well-performing, cannot be effective. The results suggest that the current system is not well conditioned for the activities of the relevant institutions and there is a considerable gap in this respect. 
Table 5 Mean, standard deviation, variance and ranking of components and their dimensions. Source: Author

\begin{tabular}{|c|c|c|c|c|}
\hline Component & Dimension of component & Variance & $\mathrm{SD}$ & Mean \\
\hline \multirow[t]{3}{*}{ Lack of clear vision } & Lack of supra-institutional vision & .273 & .52 & 3.57 \\
\hline & Lack of purposefulness & .176 & .42 & 3.48 \\
\hline & Total & .179 & .424 & 3.52 \\
\hline \multirow{3}{*}{$\begin{array}{l}\text { The type of decision-making and the level of duties and } \\
\text { powers concentration }\end{array}$} & Non-participatory decision making & .256 & .51 & 3.38 \\
\hline & Centralized power structure & .322 & .57 & 3.52 \\
\hline & Total & .163 & .404 & 3.55 \\
\hline \multirow[t]{3}{*}{ Lack of integrated policy } & $\begin{array}{l}\text { Weakness in coordination of urban land politics with } \\
\text { other sectors policies }\end{array}$ & .162 & .40 & 3.68 \\
\hline & Lack of coordination between documents & .423 & .65 & 3.34 \\
\hline & Total & .218 & .467 & 3.51 \\
\hline \multirow[t]{6}{*}{ The lack of integrated institutions } & Inter-institutional weak coordination & .256 & .51 & 3.38 \\
\hline & Reduction of Inter-institutional Social Capital & .195 & .44 & 3.36 \\
\hline & Lack of coordinated behavior & .256 & .51 & 3.38 \\
\hline & Lack of necessary institutional arrangements & .256 & .51 & 3.38 \\
\hline & Lack of necessary legal arrangements & .256 & .51 & 3.38 \\
\hline & Total & .123 & .351 & 3.39 \\
\hline \multirow[t]{2}{*}{ Institutional Capacity } & Ability of institutions & .256 & .5 & 46.3 \\
\hline & Education and learning & .322 & .56 & 59.3 \\
\hline \multirow[t]{2}{*}{ Effectiveness of state intervention } & Direct intervention & & .74 & 47.3 \\
\hline & Indirect intervention & .322 & .57 & 69.3 \\
\hline
\end{tabular}

Table 6 Results of the Spearman test

\begin{tabular}{|c|c|c|c|c|c|c|c|}
\hline \multicolumn{8}{|l|}{ Correlations } \\
\hline $\begin{array}{l}\text { Integration of } \\
\text { institutions }\end{array}$ & $\begin{array}{l}\text { Coordination } \\
\text { of policies }\end{array}$ & $\begin{array}{l}\text { Type of } \\
\text { decision } \\
\text { making }\end{array}$ & $\begin{array}{l}\text { Distinct } \\
\text { vision }\end{array}$ & $\begin{array}{l}\text { Institutional } \\
\text { capacity }\end{array}$ & $\begin{array}{l}\text { Effectiveness of } \\
\text { intervention }\end{array}$ & & \\
\hline .09 & $.330 *$ & $.375^{* *}$ & .188 & $.302 *$ & 1 & $\begin{array}{l}\text { Spearman } \\
\text { correlation } \\
\text { coefficient }\end{array}$ & $\begin{array}{l}\text { Effectiveness of } \\
\text { state intervention }\end{array}$ \\
\hline 0 & 0 & 0 & 0 & 0 & 0 & Sig. (2-tailed) & \\
\hline 350 & 350 & 350 & 350 & 350 & 350 & $\mathrm{~N}$ & \\
\hline
\end{tabular}

*Correlation is significant at the .05 level (2-tailed)

**Correlation is significant at the .01 level (2-tailed)

Spearman test was performed for regression analysis to identify the relationships of the components with the effectiveness of state intervention in urban land management and the internal relations of the components.

As shown in the above table, the five components showed a significant relation with the effectiveness of state intervention in urban land management ( $p$ value $=.000$ for every component). According to the results of the Spearman test, the internal relationships of the components are statistically significant ( $p=.000$ for all relationships). The highest correlation was observed between the "integration of institutions" and "distinct vision" and the lowest correlation was between the "integration of policies" and "distinct vision" (Table 7).

After establishing the existence of a positive significant relationship between the five components (as independent variables) and the effectiveness of state intervention in urban land management (as the dependent variable), a path analysis was performed on the relationship of components with each other and with the effectiveness of state 
Table 7 Correlation between components. Source: Author

\begin{tabular}{|c|c|c|c|c|c|c|}
\hline & & $\begin{array}{l}\text { Institutional } \\
\text { capacity }\end{array}$ & $\begin{array}{l}\text { Integration of } \\
\text { institutions }\end{array}$ & $\begin{array}{l}\text { Integration of } \\
\text { policies }\end{array}$ & $\begin{array}{l}\text { Type of decision } \\
\text { making }\end{array}$ & $\begin{array}{l}\text { Distinct } \\
\text { vision }\end{array}$ \\
\hline \multirow[t]{3}{*}{ Distinct vision } & $\begin{array}{l}\text { Spearman correlation } \\
\text { coefficient }\end{array}$ & $.547 * *$ & $.580 * *$ & $.435^{* *}$ & $.509 * *$ & 1 \\
\hline & Sig. (2-tailed) & 0 & 0 & 0 & 0 & 0 \\
\hline & $\mathrm{N}$ & 350 & 350 & 350 & 350 & 350 \\
\hline \multirow[t]{3}{*}{$\begin{array}{l}\text { Type of decision } \\
\text { making }\end{array}$} & $\begin{array}{l}\text { Spearman correlation } \\
\text { coefficient }\end{array}$ & $.543 * *$ & $.453 * *$ & $.476 * *$ & 1 & $.509 * *$ \\
\hline & Sig. (2-tailed) & 0 & 0 & 0 & 0 & 0 \\
\hline & $\mathrm{N}$ & 350 & 350 & 350 & 350 & 350 \\
\hline \multirow[t]{3}{*}{$\begin{array}{l}\text { Integration of } \\
\text { policies }\end{array}$} & $\begin{array}{l}\text { Spearman correlation } \\
\text { coefficient }\end{array}$ & $.556^{* *}$ & $.559 * *$ & 1 & $.476 * *$ & $.435 * *$ \\
\hline & Sig. (2-tailed) & 0 & 0 & 0 & 0 & 0 \\
\hline & $\mathrm{N}$ & 350 & 350 & 350 & 350 & 350 \\
\hline \multirow[t]{3}{*}{$\begin{array}{l}\text { Integration of } \\
\text { institutions }\end{array}$} & $\begin{array}{l}\text { Spearman correlation } \\
\text { coefficient }\end{array}$ & $.520 * *$ & 1 & $.559 * *$ & $.453 * *$ & $.580 * *$ \\
\hline & Sig. (2-tailed) & 0 & 0 & 0 & 0 & 0 \\
\hline & $\mathrm{N}$ & 350 & 350 & 350 & 350 & 350 \\
\hline \multirow[t]{3}{*}{$\begin{array}{l}\text { Institutional } \\
\text { capacity }\end{array}$} & $\begin{array}{l}\text { Spearman correlation } \\
\text { coefficient }\end{array}$ & 1 & $.520 * *$ & $.556 * *$ & $.543 * *$ & $.547 * *$ \\
\hline & Sig. (2-tailed) & 0 & 0 & 0 & 0 & 0 \\
\hline & $\mathrm{N}$ & 350 & 350 & 350 & 350 & 350 \\
\hline
\end{tabular}

Correlation is significant at the .01 level (2-tailed)

Fig. 2 Path analysis and coefficients

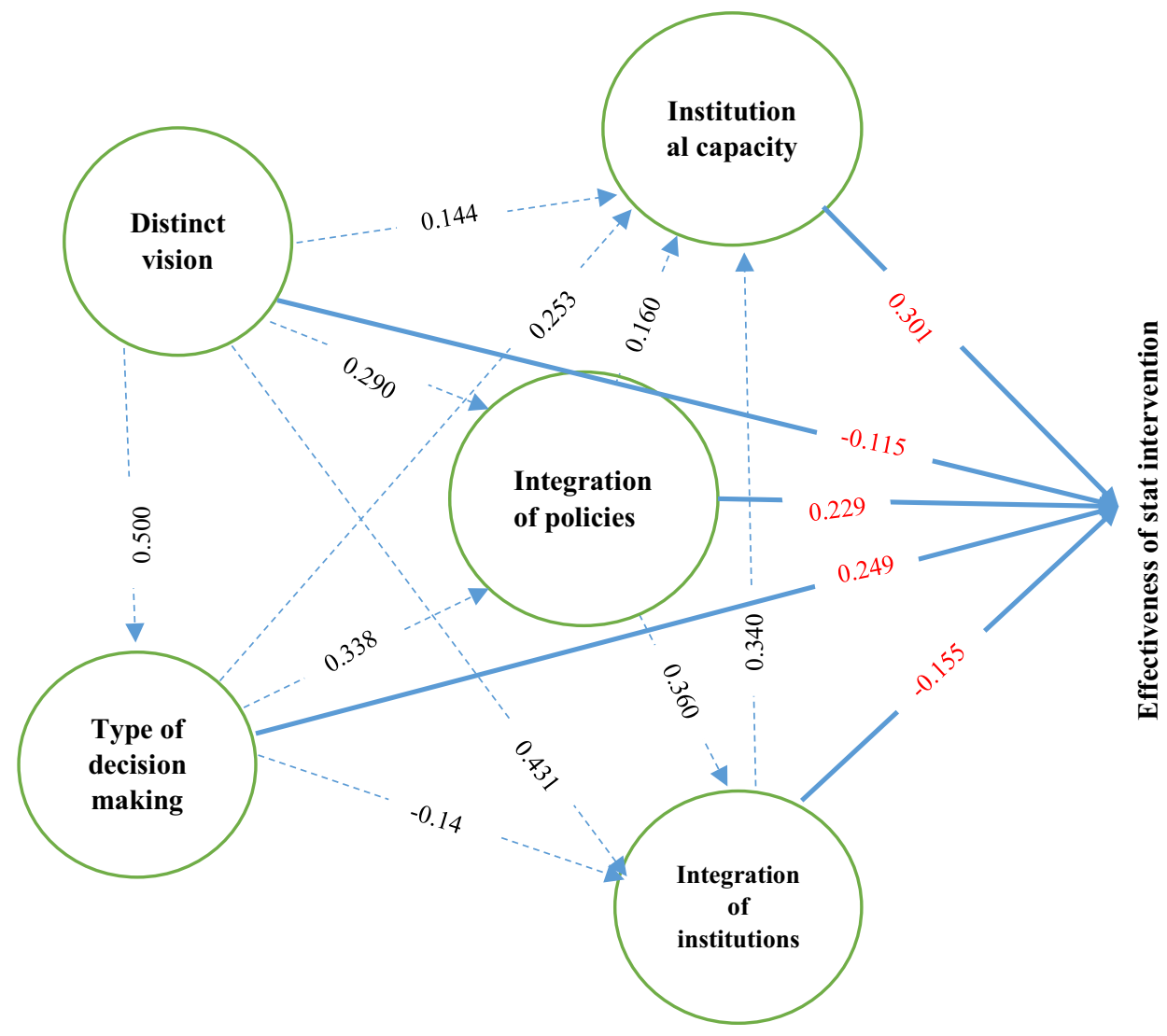


Table 8 Direct and indirect effects of variables on the effectiveness of state intervention. Sources: Author

\begin{tabular}{llcl}
\hline Total & Indirect effect & Direct effect & Independent variables \\
\hline .301 & & .301 & Institutional capacity at institutional and individual level \\
-.05266 & .10234 & -.155 & Integration of institutions \\
.258202 & .029202 & .229 & Coordination of policies \\
.355759 & .106759 & .249 & Type of decision making \\
.130649 & .245649 & -.115 & Distinct vision \\
\hline
\end{tabular}

intervention in urban land management. In the path analysis diagram, bold lines represent the direct effects of independent variables on the dependent variable and the thin dotted lines represent the relationships of independent variables with each other and their indirect effects on the dependent variable. The total effect of independent variables on the dependent variable is the sum of their direct and indirect effects (Fig. 2; Tables 8, 9).

Table 10 shows the effect of each independent variable on the final dependent variable (effectiveness of state intervention in urban land management). According to this table, institutional capacity at individual and institutional levels has had the highest effect and the lack of a specific vision has had the least effect on the effectiveness of state

Table 9 Ranking of factors in IFEM and EFEM. Source: Author

\begin{tabular}{lll}
\hline Rank & Internal factors & External factors \\
\hline 4 & High strength & Exceptional opportunity \\
3 & Normal strength & Normal opportunity \\
2 & Normal weakness & Normal threat \\
1 & Critical weakness & Serious threat \\
\hline
\end{tabular}

intervention. In other words, as we move from individual capacity to institutional capacity and higher, the direct impact on the effectiveness of state intervention decreases and vice versa.

\subsection{Modeling with SWOT analysis}

Using the SWOT method, the effect of variables on the effectiveness of state intervention in urban land management in Tehran was modeled through the following steps.

Step 1 Building the internal factor evaluation matrix (IFEM) and the external factor evaluation matrix (EFEM) for the effectiveness of state intervention in urban land management in Tehran. For this purpose, the key internal factors, including strengths and weaknesses, and the key external factors, including opportunities and threats, were identified through consultation with experts. Internal and external factors were scored according to the average of scores awarded to each factor by the experts. This was done such that the total score of internal factors or external factors would not exceed 1
Table 10 Summary of IFEM and EFEM. Source: Author

\begin{tabular}{llll}
\hline Factor & Key factors & Score & Coefficient \\
\hline Internal & Total strengths & 1.32 & .38 \\
& Total weaknesses & .68 & .62 \\
& Total scores of strengths and weaknesses & 2 & 1 \\
\multirow{3}{*}{ External } & Total opportunities & 1.73 & .5 \\
& Total threats & 1.93 & .5 \\
& Total scores of opportunities and threats & 3.66 & 1 \\
\hline
\end{tabular}


Table 11 Integration of internal and external factors into the SWOT table. Source: Author

\begin{tabular}{lll}
\hline Threat & Opportunity & Internal/external factors \\
\hline ST & SO & Strength \\
WT & WO & Weakness \\
\hline
\end{tabular}

Step 2 Data analysis and strategy formulation: this analysis was performed using the SWOT method, spatial matrix, and internal and external factors matrix

Table 12 Strategies for enhancing the effectiveness of state intervention in urban land management based on QSPM results. Source: Author

\begin{tabular}{|c|c|c|c|c|}
\hline Change & Rank & Attractiveness & $\begin{array}{l}\text { Applicable proposed strategy based on results of IFEM; EFEM matrix and "The SPACE } \\
\text { Matrix" graph }\end{array}$ & Strategy \\
\hline Medium & 1 & 4.36 & Developing an integrated strategic policy in line with vision & WT3 \\
\hline Fundamental & 2 & 4.32 & Delegation of authority to local institutions & TS1 \\
\hline Fundamental & 3 & 3.61 & $\begin{array}{l}\text { Empowering the market (offering and leasing land at a free market rate) and setting the stage } \\
\text { for the more active presence of the private, cooperative and public sectors. Accept the duties } \\
\text { that the above sectors are not willing to attend in those areas by the state }\end{array}$ & WT4 \\
\hline Medium & 4 & 3.44 & Developing a clear vision for state intervention in urban land management & WT2 \\
\hline Medium & 5 & 3.36 & $\begin{array}{l}\text { Changing the type of direct intervention (use of land readjustment) along with the use of } \\
\text { indirect intervention tools such as taxes and exemptions and... to balance the land and } \\
\text { housing market }\end{array}$ & $\mathrm{SO} 2$ \\
\hline Medium & 6 & 3.28 & $\begin{array}{l}\text { Create a spatial and descriptive database. Creating a level of access to all relevant institutions } \\
\text { in appropriate land management }\end{array}$ & TS3 \\
\hline Partial & 7 & 3.26 & The use of worn tissue as a source of housing supply & $\mathrm{SO} 3$ \\
\hline Medium & 8 & 3.02 & $\begin{array}{l}\text { Providing context for the participation of all stakeholders (stakeholders) in decision making } \\
\text { and specialized councils and policy formulation }\end{array}$ & TS4 \\
\hline Medium & 9 & 2.98 & $\begin{array}{l}\text { Establishment of mechanisms for adjusting national and provincial regulations and } \\
\text { regulations by local institutions in order to adapt to local conditions and reduce the lack of } \\
\text { transparency and multiplicity of higher-level laws }\end{array}$ & TS5 \\
\hline Medium & 10 & 2.98 & $\begin{array}{l}\text { Reducing the effective demand for land and housing, and simultaneously increasing supply in } \\
\text { land benefiting from services (vacant areas within the boundary and the worn out texture) } \\
\text { and achieving desirable densities }\end{array}$ & TS6 \\
\hline Partial & 11 & 2.9 & $\begin{array}{l}\text { Establishment of a mechanism for meritocracy and post-employment monitoring and } \\
\text { evaluation of staff performance and Establishing a platform for advancement and } \\
\text { meritocracy }\end{array}$ & OW4 \\
\hline Medium & 12 & 2.89 & $\begin{array}{l}\text { Establishing a council or committee or institution to enhance coordination between } \\
\text { institutions }\end{array}$ & OW3 \\
\hline Medium & 13 & 2.88 & $\begin{array}{l}\text { Deleting multiple institutions of land tenure and aggregating tasks, if possible, in one } \\
\text { institution }\end{array}$ & OW1 \\
\hline Fundamental & 14 & 2.43 & $\begin{array}{l}\text { Changing the general attitude from direct intervention to indirect intervention and reducing } \\
\text { state ownership and addressing regulatory and control tasks }\end{array}$ & SO1 \\
\hline Partial & 15 & 2 & $\begin{array}{l}\text { Reforming the organization chart and addressing the gaps in capacity and strengthening the } \\
\text { current state intervention }\end{array}$ & WT1 \\
\hline Medium & 16 & 2 & Reducing commissions and councils in the field of land ownership and land use & OW2 \\
\hline Fundamental & 17 & 2 & Assignment of authority to local public bodies (councils and municipalities) & TS2 \\
\hline
\end{tabular}


Fig. 3 Final strategy based on the results of IFEM and EFEM
IFEM

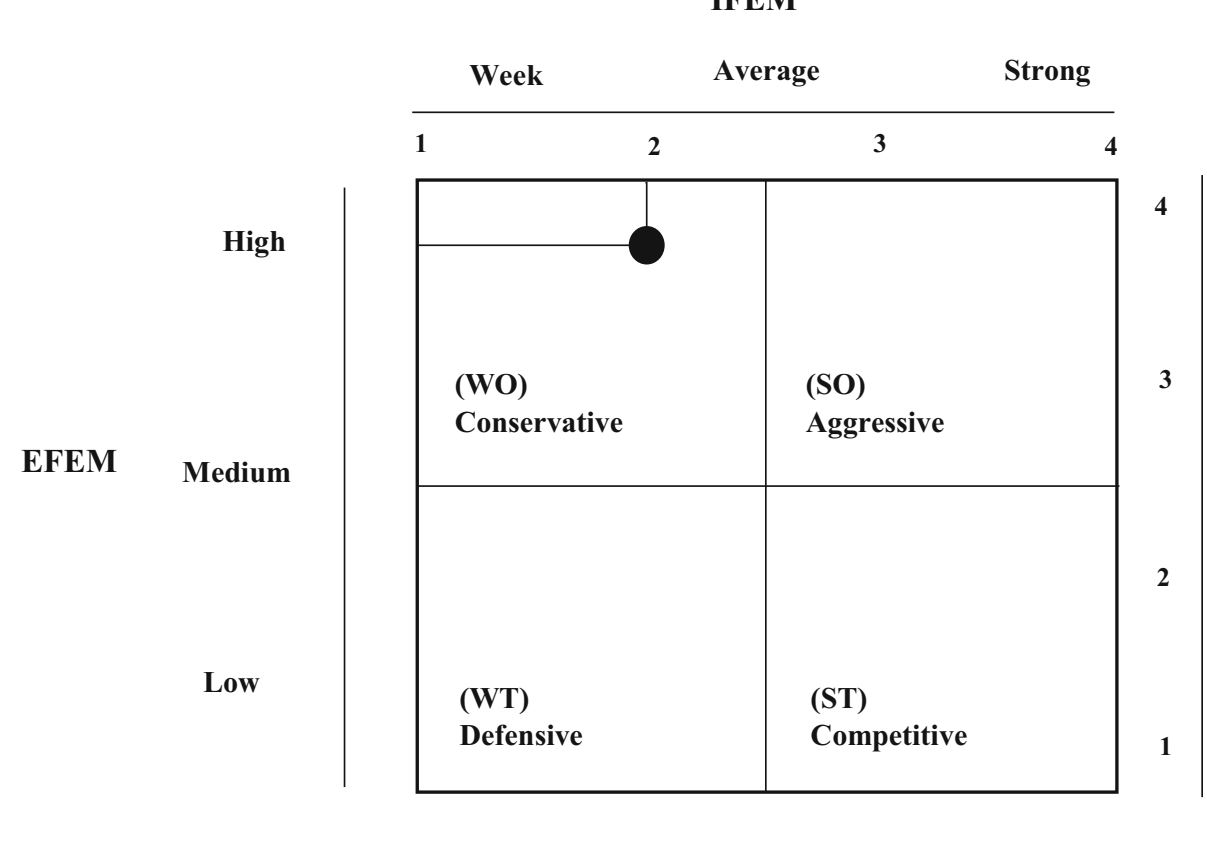

Step 3 Weighting strategic factors: the relative attractiveness of strategies was determined and they were ranked based on their scores. These scores were given according to the results of the questionnaires distributed among experts and the results presented in Table 11. Finally, the information obtained from the analysis and the QSPM matrix was used to choose the best strategy

In Table 9, internal and external factors are ranked based on the rankings of each factor. Among the factors with positive effects (strengths and opportunities), Factor No. 4 has the highest and Factor No. 3 has the lowest ranking. Among the factors with negative effects (weaknesses and threats), the highest and lowest ranks belong to Factor No. 2 and Factor No. 1, respectively.

\subsubsection{Strategy development}

After forming the SWOT table with internal factors (strengths and weaknesses) and external factors (opportunities and threats), as shown in Table 12, land management strategies were developed by integrating the internal factors with the external ones into a two-by-two matrix (with internal factors in the rows and external factors in the columns). According to the definitions of strategic management, strategies derived from strategic analysis (such as SWOT analysis) can be categorized into four types: aggressive or development strategies, conservative strategies, competitive strategies, and defensive strategies.

\subsubsection{Comparison of suggested strategies based on the attractiveness and QSPM results}

According to the scores earned by internal and external factors (Fig. 3), we must first start with conservative strategies.

The attractiveness of each proposed strategy in terms of each internal factor (strengths and weaknesses) and external factor (opportunities and threats) was computed. Then, strategies were prioritized based on their aggregate score. 


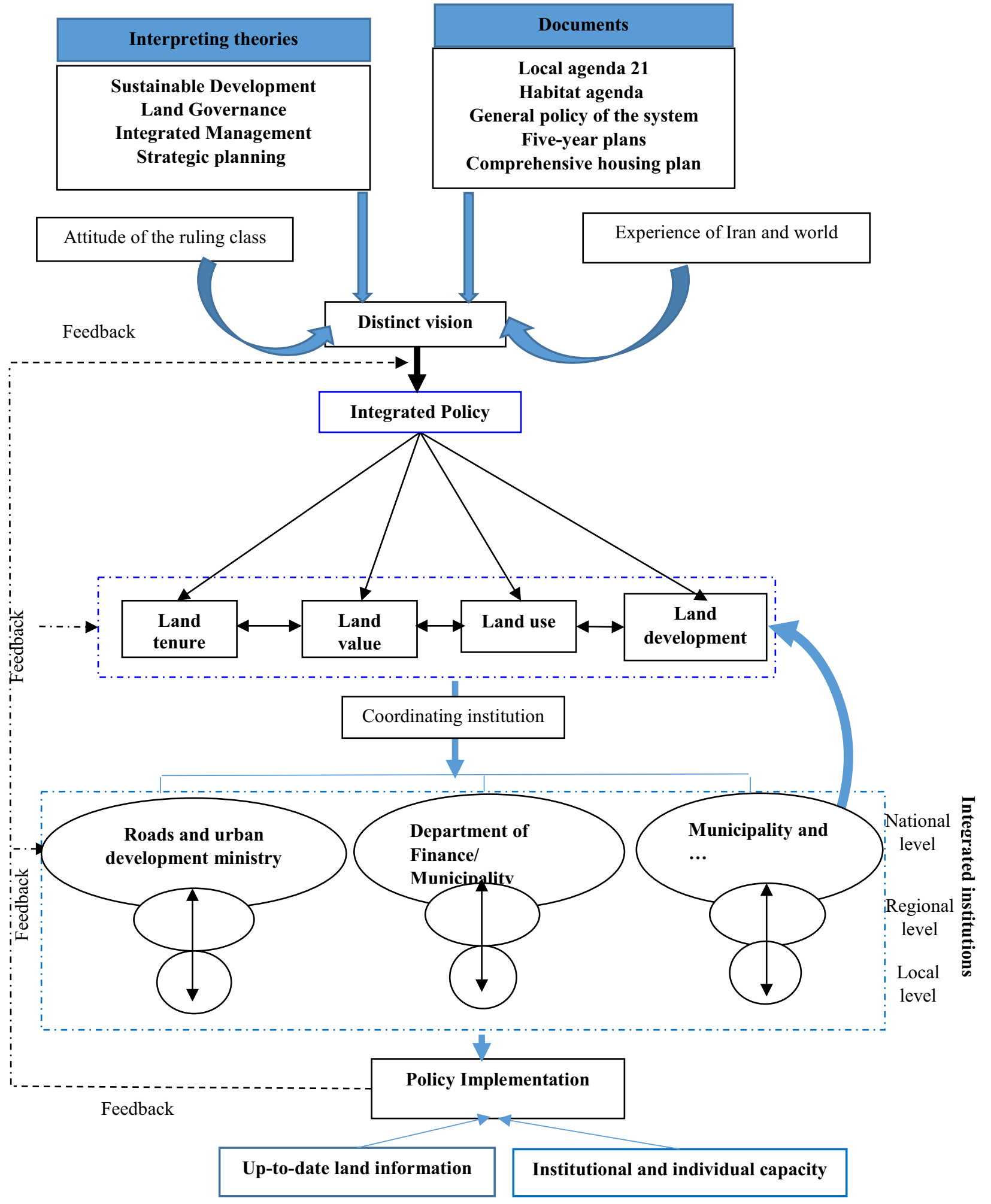

Fig. 4 Appropriate state intervention pattern in Iran's land management 


\subsubsection{Prioritization of suggested strategies}

Using the key factors identified in the internal and external environment as the basis of work, strategies were developed to minimize internal weaknesses and external threats and to maximize internal strengths and external opportunities. Since all of these strategies could minimize the weaknesses and threats and maximize the strengths and opportunities, experts were asked to rate the strategies in terms of attractiveness on a scale of 1-3 (the higher the score, the more attractive the strategy).

Strategies can also be classified based on whether they prescribe fundamental change or partial change (based on the level and type of changes at the institutional level). Here, strategies were divided into three classes based on the type and extent of the resulting changes: partial, fundamental, and moderate. Hence, strategies have to be chosen with attention to these changes as well as their cost and benefits. Otherwise, the adoption of an ill-suited strategy can cause irreparable damage to the system.

\section{Conclusion}

According to the research question, we were trying to design an optimal model for urban land management in Tehran. Our goal in this research was to design an optimal model for urban land management and to achieve this goal, we have designed the following question:

\section{What is the optimal pattern for state intervention in urban land management in Tehran?}

The results suggest that, at present, the studied system suffers from a lack of vision and undesirably centralized decision making. Also, it has a poor institutional capacity at both national and local government levels. In this system, urban land policies are inconsistent both vertically and horizontally, because there is no authority to devise an integrated policy and plan coordination. Thus, the views of stakeholders, actors, and beneficiaries in the area of land management are ignored. As a result, the institutions responsible for implementing the policies often come into conflict with each other. Remedying this situation requires, first and foremost, formulating a clear (supra-institutional) vision for sustainable land management, in which the role of state intervention in urban land management is clearly defined and the responsibilities of central government, local institutions, and the private sector are precisely differentiated. The purpose of this endeavor must be to compensate for the disadvantages/shortcomings of urban land market performance. With such a vision, it is possible to provide a platform for the adoption of integrated policies and strategic alignment among the relevant institutions.
Another goal should be to pursue capacity building at local institutions, which can be achieved through delegation of power, responsibilities and resources and the provision of necessary legal instruments. Success in this regard means local institutions, with their decentralized powers, will be able to negotiate with regional and national institutions in regard to the assigned tasks. The above-described pattern of state intervention in urban land management is presented in Fig. 4. In the pattern of Fig. 4, a distinct vision is developed based on the experiences of successful countries, theoretical principles of the discourse, and the attitude of the ruling class. The next step after adopting a vision is to develop an integrated policy. In general, the policies adopted in the area of land administration (land development, land use, land acquisition, and property sequestration) are mutually reinforcing and complementary. Hence, while implementing these policies, the responsible institutions must act in coordination. The functions of institutions must be horizontally aligned with the institutions of other sectors. There should also be a vertical alignment between national and local institutions. Also, to achieve success, it is essential to ensure the existence of a coherent set of integrated policies and integrated institutions. In other words, the implementation of any policy requires its own institutional capacity, without which, the policy is doomed to fail. The results of this study suggest that the management of land as a local commodity should be restored to its main trustee, that is, local institutions.

Open Access This article is distributed under the terms of the Creative Commons Attribution 4.0 International License (http://crea tivecommons.org/licenses/by/4.0/), which permits unrestricted use, distribution, and reproduction in any medium, provided you give appropriate credit to the original author(s) and the source, provide a link to the Creative Commons license, and indicate if changes were made.

\section{References}

1. Platt, R. H. (2014). Land use and society: Geography, law, and public policy (3rd ed.). Washington, DC: Island Press.

2. Ryan-Collins, J., Lloyd, T., \& Macfarlane, L. (2017). Rethinking the economics of land and housing. London: Zed Books Ltd.

3. Kivell, P. (1993). Land and the city: Patterns and processes of urban change. London: Routledge.

4. UN-Habitat. (2013). UN-Habitat Global Housing Strategy Framework Document. Nirobi: Housing and Slum Upgrading Branch.

5. UN-Habitat. (2015). Global Housing Strategy: Framework Document. Nirobi: Housing and Slum Upgrading Branch.

6. Han, S. S., \& Basuki, A. (2001). The spatial pattern of land values in Jakarta. Urban Studies, 38(10), 1841-1857. https://doi.org/10. 1080/00420980120084886.

7. Wu, Y., Zhang, X., \& Shenc, L. (2011). The impact of urbanization policy on land use change: A scenario analysis. Cities, 28(2), 147-159. https://doi.org/10.1016/j.cities.2010.11.002. 
8. Shu, B., Zhang, H., Li, Y., Qu, L., \& Chen, L. (2014). Spatiotemporal variation analysis of driving forces of urban land spatial expansion using logistic regression: A case study of port towns in Taicang City, China. Habitat International, 43, 181-190. https://doi.org/10.1016/j.habitatint.2014.02.004.

9. Ahmad, F., Goparaju, L., \& Qayum, A. (2017). LULC analysis of urban spaces using Markov chain predictive model at Ranchi in India. Spatial Information Research, 25, 351. https://doi.org/10. 1007/s41324-017-0102-x.

10. He, C., Han, Q., Vries, B., Wang, X., \& Guochao, Z. (2017). Evaluation of sustainable land management in urban area: A case study of Shanghai, China. Ecological Indicators, 80, 106-113. https://doi.org/10.1016/j.ecolind.2017.05.008.

11. Meshkini, A., \& Zarghamfard, M. (2019). Housing planning; glance at Iran. Tehran: Samt Press.

12. Ye, L., \& Wu, A. M. (2014). Urbanization, land development and land financing: evidence from Chinese cities. Journal of Urban Affairs, 36, 354-368. https://doi.org/10.1111/juaf.12105.

13. Fekade, W. (2000). Deficits of formal urban land management and informal responses under rapid urban growth, an international perspective. Habitat International, 24(2), 127-150. https:// doi.org/10.1016/S0197-3975(99)00034-X.

14. Kelly, P. (2003). Urbanization and the politics of land in the Manila Region. The Annals of the American Academy of Political and Social Science, 590(1), 170-187. https://doi.org/10.1177/ 0002716203256729 .

15. Lombard, M. (2016). Land conflict in peri-urban areas: Exploring the effects of land reform on informal settlement in Mexico. Urban Studies, 53(13), 2700-2720. https://doi.org/10.1177/ 0042098015603569.

16. Shan, L., Yu, A. T. W., \& Wu, Y. (2017). Strategies for risk management in urban-rural conflict: Two case studies of land acquisition in urbanizing China. Habitat International, 59, 90-100. https://doi.org/10.1016/j.habitatint.2016.11.009.

17. UN-Habitat and International Institute of Rural Reconstruction. (2012). Handling land: Innovative tools for land governance and secure tenure. Nairobi: Global Land Tool Network.

18. Rakodi, C. (1996). Urban land policy in Zimbabwe. Environment and Planning A, 28(9), 1553-1574. https://doi.org/10.1068/ a281553.

19. Lemmen, C., Van Oosterom, P., \& Bennett, R. (2015). The land administration domain model. Land Use Policy, 49, 535-545. https://doi.org/10.1016/j.landusepol.2015.01.014.

20. Molaeiqelichi, M., Murgante, B., Yousefifeshki, M., \& Zarghamfard, M. (2017). Urbanization patterns in Iran visualized through spatial auto-correlation analysis. Spatial Information Research. https://doi.org/10.1007/s41324-017-0128-0.

21. Khorasani, M., \& Zarghamfard, M. (2017). Analyzing the impacts of spatial factors on livability of peri-urban villages. Social Indicator Research. https://doi.org/10.1007/s11205-0161546-4.

22. Fürst, Ch., Helming, K., Lorz, K., Müller, F., \& Verburg, P. H. (2013). Integrated land use and regional resource managementA cross-disciplinary dialogue on future perspectives for a sustainable development of regional resources. Journal of Environmental Management, 127, S1-S5. https://doi.org/10.1016/j. jenvman.2012.12.015.

23. He, Ch., Han, Q., de Vries, B., Wang, X., \& Guochao, Z. (2017). Evaluation of sustainable land management in urban area: A case study of Shanghai, China. Ecological Indicators, 80, 106-113. https://doi.org/10.1016/j.ecolind.2017.05.008.
24. Nubi, T. G., \& Ajoku, C. (2011). Nexus between effective land management and housing delivery in Lagos. Environment and Urbanization, 23(1), 285-303. https://doi.org/10.1177/ 0956247810396988.

25. El Araby, M. (2003). The role of the state in managing urban land supply and price. Habitat International, 27, 429-458.

26. Harvey, D. (1973). Social justice and the city. Athens: University of Georgia Press.

27. Rithmire, M. (2013). Land politics and local state capacities: The political economy of urban change in China. The China Quarterly, 216, 1-24. https://doi.org/10.1017/S0305741013001033.

28. Lefebvre, H. (1991). The production of space (D. NicholsonSmith, Trans.). Oxford: Blackwell.

29. Fainstein, S. (2012). Land value capture and justice. Cambridge: Lincoln Institute of Land Policy. ISBN 978-1-55844-227-6.

30. George, H. (1879). Progress and poverty: An inquiry into the cause of industrial depressions and of increase of want with increase of wealth; The remedy. Garden City, NY: Doubleday.

31. Stubbs, M., Lemon, M., \& Longhurst, P. (2000). Intelligent urban management: Learning to manage and managing to learn together for a change. Urban Studies, 37(10), 1801-1811. https://doi.org/ 10.1080/00420980020080421.

32. Gielen, D. M., Salas, I. M., \& Cuadrado, J. M. (2017). International comparison of the changing dynamics of governance approaches to land development and their results for public value capture. Cities, 71(2017), 123-134. https://doi.org/10.1016/j. cities.2017.05.012.

33. Van Dijk, T., \& van der Vlist, A. (2014). On the interaction between landownership and regional designs for land development. Urban Studies, 52(10), 1899-1914. https://doi.org/10.1177/ 0042098014544764.

34. Thompson, R. H. (2004). Overcoming barriers to ecologically sensitive land management: Conservation subdivisions, green developments, and the development of a land ethic. Journal of Planning Education and Research, 24(2), 141-153. https://doi. org/10.1177/0739456X04269860.

35. Garba, S. B., \& Al-Mubaiyedh, S. (1999). An assessment framework for public urban land management intervention. Land Use Policy, 16, 269-279.

36. Gielen, D. M. (2016). Proposal of land readjustment for the Netherlands: An analysis of its effectiveness from an international perspective. Cities, 53, 78-86. https://doi.org/10.1016/j. cities.2016.02.001.

37. Pourmohammadi, M. R. (1993). Methods of government intervention in the urban land market. Journal of Growth and Education of Geography, 36, 14-19.

38. Archer, R. W. (1994). Urban land consolidation for metropolitan Jakarta expansion, 1990-2010. Habitat International, 18(4), 37-52. https://doi.org/10.1016/0197-3975(94)90016-7.

39. Obeng-Odoom, F. (2015). Understanding land reform in Ghana: A critical postcolonial institutional approach. Review of Radical Political Economics, 48(4), 661-680. https://doi.org/10.1177/ 0486613415603161

40. Roy, V. P. N. (2016). Land reforms, land markets and urban transformation identifying some long run impacts of land reforms from Kerala, India. Journal of Land and Rural Studies, 4(2), 123-139. https://doi.org/10.1177/2321024916640067.

Publisher's Note Springer Nature remains neutral with regard to jurisdictional claims in published maps and institutional affiliations. 